\title{
THEISM IN HISTORICAL PERSPECTIVE
}

\author{
TIMOTHY CHAPPELL
}

The Open University, UK

\begin{abstract}
I will discuss some familiar problems in the philosophy of religion which arise for theistic belief. I will argue that it may be most worthwhile to focus on a particular sort of theistic belief, capital-T Theism, central to which is a particular conception both of God and of the believer's relation to God. At the heart of Theism in this sense is the continuing experience of God, both individual and collective. Compared with the evidence for Theistic belief that is provided by this experiential contact with God, most of the usually-considered arguments for and against God's existence are secondary.
\end{abstract}

Of man's whole terrestrial possessions and attainments, unspeakably the noblest are his Symbols, divine or divine-seeming; under which he marches and fights, with victorious assurance, in this life-battle; what we can call his Realised Ideals. Of which Realised Ideals, omitting the rest, consider only [] his church. The church; what a word was there; richer than Golconda and the treasures of the world! In the heart of the remotest mountains rises the little Kirk; the dead all slumbering around it, under their white memorialstones, 'in hope of a happy Resurrection':- dull wert thou, O reader, if never in any hour (say of moaning midnight, when such Kirk hung spectral in the sky, and Being was as if swallowed up in darkness) it spoke to thee-things unspeakable, that went into thy soul's soul. Strong was he that had a Church, what we can call a Church: he stood thereby, though in the centre of Immensities, in the conflux of Eternities', yet manlike towards God and man; the vague shoreless Universe had become for him a firm city, and dwelling which he knew. Such virtue was in Belief; in these words, well-spoken: I believe. Well might men prize their Credo, and raise stateliest Temples for it, and reverend Hierarchies, and give it the tithe of their substance; it was worth living and dying for.

(Thomas Carlyle, The French Revolution, Book 1, Chapter II) 
I.

First we should distinguish theism from mere belief in the supernatural. The latter, illustrated by ghost-stories, tales of second sight, apotropaic rituals and sacrifices to prevent the failure of a harvest or a navy, the consulting of the sacred geese, and the throwing of the salt always over one's left shoulder, is a human universal, and was pretty well certainly known in one form or another even to our Pleistocene ancestors: primus in orbe deos fecit timor. ${ }^{1}$ Another name for it, among those who disbelieve in it or are hostile, is superstition.

And the former, theism? The Shorter Oxford Dictionary says that theism is "belief in a deity or deities, as opp. to atheism"2 . But-a second distinctionthe kind of theism I want to focus on here is more specific than this. Theism in my sense, Theism with a capital $\mathrm{T}$, is belief not in deities but in God with a capital G. This is a much less universal phenomenon than supernaturalism/superstition. It has a historical particularity; in the case that unites the histories of first Asia, then Europe and Africa, then the Americas, and finally Oceania, the Judaeo-Christian-Islamic tradition, ${ }^{3}$ we can more or less see where Theism begins. It begins with the writing of the first chapter of Genesis, where the author makes it as clear as he knows how that the God of whom he speaks, Yahweh, is not just another heavenly being like the sun or the moon, but the sun and moon's creator. ${ }^{4}$

1 "It was fear that first made gods in the world", Statius, Thebaid 3.661.

${ }^{2}$ Third edition, 1933, Oxford: Clarendon Press, sv. In a separate entry, the SED also says that theism is a "morbid condition" "caused by excessive tea-drinking". No doubt Anglicanism is the secret connection here.

${ }^{3}$ In discussing this tradition I shall talk mostly about the Christian part of it. No offence lies, I hope, in speaking mainly of what I know. Perhaps there would be offence in speaking ignorantly of what I do not know.

${ }^{4}$ Of course it is likely that Theism emerged from a world view in which there was "one Big God and many sub-deities, where the latter are personified attributes or aspects of the nature of the Big God. The unsophisticated can take the sub-gods seriously and worship them; the sophisticated can still be intellectually monotheists, but allow the subgod cults on practical or aesthetic grounds. Hinduism seems to work like this [today]. So did Yahwism ... where the 'host of heaven' was understood to be the gods of the Gentiles, also identified as angels and planetary powers, who each had their allotted sphere of authority under Yahweh; but Israel had direct access to the Big God through the Torah." (From correspondence with Jeffrey John, to whom thanks.) 
The difference between Theism as belief in God and theism as belief in deities is that the latter can easily be just another variety of supernaturalism. Especially where the deities are small and local enough, there seems little difference in principle between believing in such deities and believing in fairies or ghosts: think of nature-gods like Iris the rainbow-goddess, or Freya/Persephone of the harvest, or Thor the thunder-god. The classical pagan gods were very frequently of this sort, as were the deities of pagan Norway and Britain and Mexico. In another common pattern, pagan deities arose by "euhemerising" apotheosis-by the route from being a human hero to occupying yet another alcove in the cluttered and haphazard pantheon of (say) the Rome of late antiquity. This was a route, indeed, that mortal Roman emperors regularly trod. Even Greek generals sometimes took it too. ${ }^{5}$

The contrast between any such view and what I am calling Theism, as it showed up in the late-Roman context, is well put by the great French historian Paul Veyne. He notes first the "gigantism" of the Christian Theists' God:

The originality of Christianity lies not in its so-called monotheism ${ }^{6}$ but in the gigantic nature of its god, the creator of both heaven and earth: it is a gigantism that is alien to the pagan gods and is inherited from the god of the Bible. This biblical god was so huge that, despite his anthropomorphism (humankind was created in his image), it was possible for him to become a metaphysical god: even while retaining his human, passionate and protective character, the gigantic scale of the Judaic god allowed him eventually to take on the role of the founder and creator of the cosmic order. (Veyne p.20)

Besides this "gigantism," it was the "human, passionate, and protective character" of the Christians' god that, Veyne argues, set Christian Theism apart from the chaotic polytheism of the surrounding society. There one found only an ill-defined assortment of quirky, sinister,

\footnotetext{
${ }^{5}$ In the Roman world, one thinks at once of the posthumous cult of Divus Augustus and of pretty well every later pagan emperor-as ironically referred to by Vespasian on his death-bed: "I think I am about to become a god". Apotheosis was rarer in the classical Greek world, but there is the story of Alexander at the shrine of Zeus Ammon in Egypt "hearing" that he is Zeus's son, or Lysander being accorded divine honours in Samos: see http://www.iranica.com/articles/lysander . (Thanks to Elton Barker for discussion.)

${ }^{6}$ Veyne doubts that Christianity is strictly speaking monotheistic.
} 
unpredictable, highly localised, and at best conditionally benign daemons. But here was a universal and omnipresent God of "infinite mercy," caring unconditionally "about the fate of each and every human soul, including mine and yours," with whom what was on offer was "a mutual and passionate relationship of love and authority" (Veyne p.23). As Veyne shows, there was a huge difference between the effects of the two religions on the working psychology of anyone actually practising either. And that contrast nearly always worked in Theism's favour.

For whoever accepted the Christian faith, life became more intense, more organised, and was placed under greater pressure. An individual had to conform to a rule that marked him or her out ... in exchange, his or her life suddenly acquired an eternal significance within a cosmic plan, something that no philosophy or paganism could confer. Paganism left human life exactly as it was, an ephemeral amalgam of details. Thanks to the Christian god, that life received the unity of a magnetic field in which every action and every internal response took on a meaning, either good or bad. This meaning ... steered the believer towards an absolute and eternal entity that was not a mere principle but a great living being. (Veyne p.19)

Theism is just this combination of belief in an absolute and all-powerful God, utterly external and out there ("transcendent"), who is yet also intimately known within the believer ("immanent") as moral authority, direction for life, warning or encouraging adviser, saviour, answerer of prayers, friend-sometimes even as lover. To any more austerely classical pagan mind, even the Theist's belief that his God answered prayer is likely to have seemed an absurdity: Dios gar dysparaitêtoi phrenes. ${ }^{7}$ As for the fact that the Theist's relationship with God could be conceivable in romantic or even quasi-erotic terms, to any rationalistically-minded outsider this must seem one of the most astonishing, not to say outrageous, things about Theism. Yet the evidence, across the whole spectrum of different Theist traditions, is quite unequivocal. ${ }^{8}$

7 "For prayers do not deflect the mind of Zeus", Aeschylus, Prometheus Vinctus 34.

8 Just for starters: Rabindranath Tagore addresses his God (who, as often in sophisticated forms of the ostensibly polytheistic religion Hinduism, is pretty clearly the God of Theism) as "beloved of my heart," Jalal ud-Din Rumi writes that "Our death is our wedding with eternity," Jesus calls himself, and John the Baptist calls him, the bridegroom, St Teresa of Avila's The Interior Castle is an entire book (one of many) on 
It is this combination of immanence and transcendence that makes the Theist view so psychologically compelling. If I adopt Theism then even within little me there will lovingly dwell the God of everything - as in the manger at Bethlehem, or as in Mary: "For he that is mighty hath done great things in me, and holy is his name" (Luke 1.49). It is easy to see how this combination serves, to give the believer a sense of the importance of his life and actions: "the vague shoreless Universe" has "become for him a firm city, and dwelling which he" knows. Many scholars think that Christian moralists make more than the classical pagans did of the virtue of humility. If that is so, perhaps it is because those who dare to believe that their own small hearts can become the dwelling-place of the infinite God have the more need of humility. ${ }^{9}$ Throughout history the Theists' version of this idea of the divine indwelling or enthousiasmos, ${ }^{10}$ with the cosmic importance of the quotidian as its corollary, has seeded megalomania, self-deception, self-absorption, fantasism, fanaticism, spiritual fascism, and psychological manipulation and abuse. It has also been one of the principal sources of most of the permanent cultural achievements of our civilisation.

At the heart of Theism, transcendence combines with immanence in the intoxicating thought that the infinite is also the intimate: God himself has a plan even for my life. Constantine had this belief-Veyne p.51 quotes him telling the Council of Nicaea his reasons for thinking that he is "particularly distinguished by a special decision of Providence." (And

the mystical marriage of the soul to Christ, John Donne says in a famous Sonnet that he will be "nor ever chaste, except thou ravish me," Simone Weil remarks, apparently quite casually, that "le mystique tourne violemment vers Dieu la faculté d'amour et de désir dont l'énergie sexuelle constitue le fondement physique" (SW, cited on p.41, tome VI, vol.2), and then in the Bible there is Psalm 45, and the forsaken bride of Hosea and deutero-Isaiah, and more than one Gospel parable, and "the wedding feast of the lamb" in Revelation - and the Song of Songs. (Rabbi Akiba: "The whole world is worth less than the day on which the Song of Songs was given to Israel . . . all the scriptures are holy, but the Song of Songs is the Holy of Holies".)

${ }^{9}$ Compare also the Kantian thesis that the Enlightenment deity Universal Reason can find a lodging place even within me: see my "Intuition, system and the 'paradox' of deontology," pp.271-288 in Julian Wuerth and Lawrence Jost, ed., Perfecting Virtue (Cambridge: CUP 2011), at p. 283.

${ }^{10}$ The word is pre-Christian Greek. It is not only Theists who have believed that gods can enter the human breast: see e.g. Euripides' Bacchae. Or that divine action on humans can be quasi- or actually erotic: see Ovid's Metamorphoses. 
who can say that Constantine did not have good reason to think so?) William Gladstone had this belief: see the citations from his diaries in Roy Jenkins' biography. Jesus and St Paul and Augustine and Mohammed and Aquinas and St Francis and Martin Luther and John Calvin and John Knox and Ignatius Loyola and Blaise Pascal and Isaac Newton and René Descartes and John Wesley and David Livingstone and Gerard Manley Hopkins had this belief. I believe it myself. Every believer who has ever taken himself to receive divine guidance, as millions constantly do, has had this belief. Once the belief becomes credible, its attraction is almost irresistible.

This brilliant and seductive psychological appeal both to our sense of smallness and to our sense of greatness is the reason, Veyne argues, why Christianity won out in its battle with the feeble, syncretistic, and disaggregated supernaturalism of paganism; the contrast revealed Christianity as quite simply a better-designed religion. To use Veyne's word, a masterpiece: ${ }^{11}$

Certain agnostic historians may think it less than scholarly to draw up a comparison between the merits of different religions. But ... to do so is not to violate the principle of axiological neutrality any more than one does when one recognises the superiority of certain artistic or literary creations, a superiority to which Constantine's contemporaries were no more blind than we ourselves are. Why ever should the creative imagination of religions not produce masterpieces, likewise? (Veyne p.18)

II.

If our concern is not (like some busy contemporaries) to denounce Theism but to understand it, it is the perspective afforded by this notion of the Infinite Intimate that we need to start from.

Most philosophers routinely don't start from any such perspective, or even ever reach it. They start from a dictionary definition like the SOED's. They take the heart of Theism to be, not a history of vivid and direct experience of an infinite God who has a plan even for finite you, but the

${ }^{11}$ I write as a Christian-quoting Veyne, who writes as an atheist and sometime communist. 
proposition that "There is some god or gods." They marshal arguments for and against this proposition. And so we get the familiar does-God-exist debates of contemporary philosophy, in which God so incongruously shows up as a possibly-missing component in the mechanics of cosmology or evolution, part of a botched attempt at scientific explanation. Or philosophers note the troubling tension between the Theist's doctrine of the goodness of the creator and the datum of the badness of large tracts of the creation, recast doctrine and datum alike as propositions, and look for a tertium datur to resolve the clash: and so we get the problem-of-evil literature. Or philosophers take the nub of the Theistic doctrines of God's omnipotence or omniscience, or the specifically Christian doctrine of the Trinity, to be, likewise, a matter of propositions; and here again they draw our attention to the logical difficulties attending those doctrines, considered as concatenations of propositions.

The problem with this abstractly propositional approach is not that it is wrong. The problem is that, pursued in isolation, it tends to miss the foundational role of experience in Theism.

To be a Christian is to know, however deep down, and however much we forget from day to day, that our relationship with Christ is everything. Perhaps too many Christians bang on too loudly about their 'personal relationship with Jesus,' so that it sounds fake and superficial. But equally, perhaps, too many Christians keep quiet about it. Because it is true that this is the heart of it-everything else is no more than commentary. And to work on that relationship-to give it 'quality time,' to pay attention, to listen, to try to please the Beloved-is no less important than in a human marriage. (Jeffrey John, The Meaning in the Miracles (Norwich: Canterbury Press 2001), p.54)

Consider two aspects of experience, one having to do with the epistemic position, the other with the diachronic nature, of the Theist's beliefs. First, the epistemic position.

Consider someone who, like us all I assume, lives her life in the midstream of a constant deluge of the best evidence she could possibly have that external-world scepticism is false: experiential evidence. An abstractly propositional approach to external-world scepticism is bound to look slightly strange to any such person. Certainly someone in this epistemic position can understand sceptical doubts, explore them with 
interest and engagement, note with surprise-or perturbation-the difficulty of conclusively rebutting any argument of, e.g., this form:

1. If I do not know that no evil demon is deceiving me, then I do not know that I have hands.

2. I do not know that no evil demon is deceiving me.

3. So I do not know that I have hands.

Can she take such sceptical doubts seriously? Is it possible to her that external-world scepticism might be true? It is hard to see how it could be, for the reason identified by G. E. Moore ${ }^{12}$ : because her justification for denying the conclusion of the sceptical argument (3) is so much better than any justification she could possibly have for accepting its premises $(1,2)$. She is certain she has hands. If her alternatives are to deny that she is certain, or to deny one of the sceptical argument's premises, then she has every reason to pick the second alternative. She may not know which premise is false, but her certainty about the falsehood of (3) means that she is completely rational, and completely justified, in asserting "Not ((1) and (2))." Sceptical arguments like (1-3) may set her intriguing intellectual puzzles; they may even provide her with a livelihood writing about them. What they will not do is threaten her basic confidence that, for instance, she does indeed know she has hands.

They might threaten her assurance of that if it was a whole lot weaker, or if her epistemic position were strictly neutral-if she was antecedently disposed simply to consider each proposition on its logical merits in the abstract, and not disposed to take any proposition whatever to be any more or less sure than any other. But her position is precisely not neutral in this way. And the case of the Theist is parallel. As I put it above, the person considering external-world scepticism "lives her life in the midstream of a constant deluge of experiential evidence" for the existence of an external world. That sets her so far from abstract epistemic neutrality that she has every justification for weighting external-world scepticism as no more than an intriguing intellectual puzzle. Similarly, the defining feature of Theism is the Theist's experience of an infinite but intimate God; and this sets the Theist so far from abstract epistemic

${ }^{12}$ In "Our knowledge of the external world", Proceedings of the British Academy 1939. 
neutrality that she too has every justification for weighting most of the standard budget of problems for Theism found in typical philosophy of religion basically as interesting puzzles. The epistemic reasoner is certain that the world is real, on the basis of her experience; so her question about the sceptical argument is not "I wonder whether it is sound?" but "I wonder where exactly it goes wrong?" The Theist is certain ${ }^{13}$ that God is real, on the basis of her experience; so her question about antiTheistic arguments is not whether they prove that there is no God, but how exactly they fail to prove that.

Contemporary opponents of Theism tend to assume that everyone who is rational starts in the same epistemically neutral place, and assesses the arguments for Theism, in the timeless abstract, from that epistemically neutral place. We might ask whether this epistemic neutrality even exists, and what use it would be to us if it did. That aside, when someone is rationally assessing an argument, the fact that her background beliefs include strong reasons for thinking that the argument's conclusion cannot be true is no objection to her rationality. The best arguments for external-world scepticism may be good arguments indeed. That does not mean that they should convince anyone. Normal people have overwhelmingly good evidence in their own experience that there is an external world, and reasonably take this to "epistemically outweigh" even the best arguments going for external-world scepticism. Likewise, the best arguments against Theism may be formidable, yet completely unpersuasive to a Theist-even a rational and fair-minded Theist. The whole point about Theism is that it claims that individuals can have overwhelmingly good experiential evidence that there is a God. To allow this experience to "epistemically outweigh" even the best antiTheist arguments is no less reasonable than the analogous move against external-world scepticism.

This notion of epistemic position helps us to understand the spirit in which Theists from strongly Theist societies like Anselm and Aquinas offer arguments for God's existence. They do so in something like the

${ }^{13}$ I do not mean to underplay the reality of doubt in religious experience, which happens to all believers some of the time, and some believers all of the time. Yet the fact that doubt happens does not undermine the basic fact I am insisting on here: that an experiential certainty of the reality of God (perhaps a fluctuating one) is characteristic of Theism. (Thanks to Jeffrey John for discussion.) 
same spirit as contemporary epistemologists who do not really doubt the external world's existence for a moment offer anti-sceptical arguments for the existence of an external world. In both cases the arguments that $\mathrm{p}$ are not evoked by a live doubt whether $\mathrm{p}$, but rather by an interest in exploring alternative possible structures of argument that might or might not support the undoubted truth that $\mathrm{p}$. Perhaps we might even say that arguments about God's existence are to the pre-Cartesian philosophical world as arguments about the external world's existence are to the postCartesian.

The notion of epistemic position also illuminates some familiar impasses in present-day debates about the philosophy of religion. For instance, critics of Theism sometimes struggle even to see their Theist interlocutors as rational, as dealing in the currency of arguments. It is sometimes cynically said that the conclusion is "the point in the argument where you stop thinking." Cynicism aside, different reasonable people can have different good reasons for being content to reach their rational resting-places at different lemmas. One respectable source of these different good reasons is different backgrounds of experience. So the atheist who finds some purely logical problem in the notion of God's omnipotence, e.g. that a God who "could do anything" neither could nor could not create a stone too heavy for Himself to lift, may conclude straight away that there cannot be a God. Whereas a Theist, confronted with the same problem, may respond "Oh, how interesting. So God's omnipotence must be beyond our understanding"; or "Ah, OK, so there is one thing that God can't do-but He is otherwise omnipotent," or "Well, this thing has a logically inconsistent description, so of course God can't do it"; ${ }^{14}$ or "Oh, so perhaps omnipotence is not what matters in thinking about God"15-or in some other way may qualify her understanding of what God is like, without in any way weakening her confidence that God is. This tenacity about God's existence may (to repeat) be perfectly rational; as if it is based upon overwhelmingly good experiential evidence

\footnotetext{
${ }^{14}$ For what it's worth this is my own response (there are plenty of others) to this old chestnut. The task that it sets for God has this description: to create a stone that cannot be lifted by an agent who can do anything. The inconsistency in this description is obvious.

${ }^{15}$ So Peter Geach, who prefers to talk about "almightiness," in his "Omnipotence" [1973], pp.63-75 in Philosophy of Religion: Selected Readings, Oxford University Press, 1998.
} 
of God's existence. That evidence does not come into the argument about the coherence of the doctrine of omnipotence. But it does, so to speak, "wait outside" the argument, to evaluate its conclusion. And someone who lacks this evidence will reasonably form a different evaluation of that conclusion from someone who has it.

I said that Theists can have "every justification for weighting most of the standard budget of problems for Theism found in typical philosophy of religion basically as interesting puzzles." Most, I said, because one standard problem in philosophy of religion is bound to be grievously more than a mere intellectual puzzle. This is the classic problem of evil.

God, says Epicurus, either wishes to prevent evils, and is unable; or he is able, and is unwilling; or he is neither willing nor able; or he is both willing and able. If he is willing and is unable, he is weak, which does not fit the character of God. If he is able and unwilling, he is malevolent, which does not fit God's character either. If he is neither willing nor able, he is both malevolent and weak, and therefore not God at all. If he is both willing and able which alone is fitting for God, from what source then are evils? Why does he not prevent them? (Lactantius, de Ira Dei (c.313 AD); the first extant formulation of Epicurus' version of the problem of evil)

Evidently Epicurus' puzzle was presented as a puzzle for believers in a God of good providence: the Stoics' God, or Lactantius' own Christian God. (Epicurus seems not to have presented it, as people often present it today, as a puzzle for believers in God. Epicurus himself apparently believed in God, just not a providential or caring one.)

Epicurus' puzzle is an intellectual puzzle, but it is not merely an intellectual puzzle. To any feeling person, the existence of evil in our world must create an emotional struggle as well as an intellectual puzzle. Theists suppose that there is a God who is good enough to want the very best for his creatures, and powerful enough to do anything He chooses. So why in Heaven's name doesn't He choose to do the very best?

One striking thing about this question is how much time Theists themselves spend asking it, while being altogether unable to answer it. ${ }^{16}$

${ }^{16}$ Indeed, Theists are often not at their best—-to put it mildly — when they think they do have "the" answer to the problem of evil; as Voltaire famously pointed out in Candide, with specific reference to Leibniz. 
Why standest thou afar off, O Lord? Why hidest thou thyself in time of trouble? (Psalm 10.1)

What is man, that thou shouldest magnify him, and that thou shouldest set thine heart upon him, and that thou shouldest visit him every morningand try him every moment? (Job 6.17-18)

Thou art indeed just, Lord, if I contend With thee; but, sir, so what I plead is just.

Why do sinners' ways prosper? And why must

Disappointment all I endeavour end?

Wert thou my enemy, $\mathrm{O}$ thou my friend,

How wouldst thou worst, I wonder, than thou dost

Defeat, thwart me? Oh, the sots and thralls of lust

Do in spare hours more thrive than I that spend,

Sir, life upon thy cause...

(Gerard Manley Hopkins; cp. Jeremiah 12.1)

My God, my God, why hast thou forsaken me? (Psalm 22.1/ Mt 27.46)

If the answer is infinite light

Why do we sleep in the dark? (Paul Simon ${ }^{17}$ )

Or, if I may be forgiven for quoting a poem of my own, "The Children's Cemetery, Balgay":

Parents' sentences on marble;

mildewed dolls beneath grown trees:

O you who mark the sparrow's fall,

did you not notice these?

You could call the whole Judaeo-Christian Theistic tradition a tradition of complaining at God. Stephen Fry, himself partly Jewish, somewhere ${ }^{18}$ has a fictional character (also Jewish) describe the Jews as "his stupid, moaning, helpless and cosmically irritating people." Perhaps that is how most Theists seem to God Himself.

${ }^{17}$ Paul Simon, "How can you live in the northeast?" on his 2006 album Surprise (Warner).

${ }^{18}$ Stephen Fry, The Hippopotamus (London: Hutchinson, 1995), p.218. 
This Theistic moaning tells us something important about Theism and the problem of evil. The critic of Theism quite often notices that she makes little or no impression on Theists by simply announcing a list of worldly mishaps, be they never so dire. The critic may conclude that Theists just display a mulish imperviousness to empirical evidence. For the Theist, however, this sort of evidence is irrelevant. Pace John Stuart Mill, ${ }^{19}$ Theists do not arrive at their Theism by doing a "value-audit" on creation: totting up the net balance of good and evil in creation, inferring that the net balance of good and evil in any Creator would have to be just the same, and concluding either that there is a universally good Creator and the discordant partial evil in the world is only "harmony not understood," or that there is no such Creator, or that the Creator is either morally ambiguous or just plain evil. Their Theism was, so to speak, already there before they even considered how things stand with the world. And it rests upon quite a different ground from any calculus of good and bad fortune in the world that might be devised; the ground of experience.

Hence Theists see the problem of evil too from a quite different epistemic position from their critics. It is not that Theists-unless they are intolerably naïve, smug, and callous-do not see evil as a problem. But it is that Theists see evil as a problem in time: a diachronic problem. ${ }^{20}$

Suppose you have a friend whom you trust deeply, on the solid evidential basis of your long and vivid experience of that friend's care for you. One day you find very strong evidence that that friend has betrayed you in some fundamental way. Is there only one rational response to this new negative evidence: to weigh the new negative against your past positive evidence and decide which counts for more?

You might think so if you were considering the question in abstraction from time, as a straight inconsistency in the propositions that constitute

${ }^{19}$ J. S. Mill, "Essay on nature," at http://www.lancs.ac.uk/users/philosophy/texts/mill on.htm: "If a tenth part of the pains which have been expended in finding benevolent adaptations in all nature had been employed in collecting evidence to blacken the character of the Creator, what scope for comment would not have been found ..." Thanks for the reference to Peter Cave.

${ }^{20} \mathrm{I}$ think it is a narrative problem too. I do not have space to pursue this here, but see Eleonore Stump, Wandering in Darkness (OUP 2010), especially her distinction between "Dominican" and "Franciscan" philosophical reasoning at the beginning. 
your evidence. But suppose you look at your evidential problem about your friend, as of course you in fact will, as a diachronic problem, a problem in time. Then you will immediately see that you have two further salient options besides insisting on reaching a verdict, right now, on nothing but the present balance of evidence. One option is to wait and see how things turn out. If you just hold off a little, then maybe a good explanation of your friend's apparent betrayal will soon become clear to you. The other option is to confront your friend. Track him down, explain how things look to you, see what he has to say for himself. In short, have a good moan at him, and see how he takes it.

Both these responses to a trusted friend's apparent betrayal seem just as rational as insisting on reaching an immediate verdict about that apparent betrayal without waiting or looking for more evidence. Indeed in imaginable particular cases, they will often be far more rational. Their rationality depends, broadly speaking, on how good are your antecedent reasons for trusting the friend.

Just likewise with the Theist's response to the problem of evil. Hers too is in no way an irrational response to the epistemic conflict confronting her as a result of that problem. She does not find herself atemporally confronted with the raw propositions "There is a morally perfect and omnipotent creator God" and "There is evil in the world," and challenged to find a way to reconcile them or weigh them off against each other in the abstract. Rather, the problem of evil typically comes to the Theist within the time-series of her experience and her life. First there is her experience of God; then there is the fact that she is confronted by some particular evil, perhaps by horrifying evil. But the time-series does not stop there. It goes on, and that gives the Theist her chance to wait and see what God might do about the evil that confronts her-and indeed to moan at God about it.

This is precisely what Theists have always done, confronted with some evil. ${ }^{21}$ This is what the Psalmist means by "my soul waits upon the Lord," an attitude that he clearly thinks is not just possible, but imperative, even in the most exigent circumstances, and even when God appears to do nothing about the evil facing her.

${ }^{21}$ Often they can also do something about the evil themselves, and so provide the answer to their own prayers. Nothing I say here is meant to rule out or occlude that possibility. 
Behold, as the eyes of servants look unto the hand of their masters, and as the eyes of a maiden unto the hand of her mistress: so our eyes wait upon the Lord our God, until that he have mercy upon us. (Psalm 123.2-4)

I say "confronted with some evil." There is a distinction between specific evils that confront Theists in specific cases, and evil in general-the sum total of evil in the whole world-that confronts the Theist all the time. But the problem of evil is about evil, and both specific evils and evil in general are varieties of that. Evil in general is a much bigger and less tractable problem than specific evils, but the theist's attitude to both general and specific evil is essentially the same. It is that you have to see it as something that happens at some point in time; and that you have to either wait patiently, or bother God impatiently, about it until God has provided a resolution.

What we must completely get away from is the idea that the world as it now exists is a rational whole. We must think of its unity not by the analogy of a picture, of which all the parts exist at once, but by the analogy of a drama where, if it is good enough, the full meaning of the first scene only becomes apparent with the final curtain; and we are in the middle of this. Consequently the world as we see it is strictly unintelligible. We can only have faith that it will become intelligible when the divine purpose, which is the explanation of it, is accomplished. (Archbishop William Temple, quoted in Iremonger, 1948, pp. 537-8)

Central to the Theist's outlook is an attitude of hope. ${ }^{22}$ Such hope might be misplaced or over-optimistic, of course. But is a hopeful attitude to the world so very obviously less rational than thinking of the world as so botched, maimed, and incompetent that any "God" who had made it would deserve only our hatred and contempt? Even if it were less rational, mightn't it still suggest a better, because more humane, way to learn to live?

[What a humane education is most deeply concerned with] is the possibility of coming into an inheritance. It has to do with no less a question than whether

${ }^{22}$ On hope cp. my "Why is faith a virtue?," Religious Studies 32 (1996), pp.27-36; reprinted (2002) in Charles Taliaferro and Philip Quinn, ed., The Blackwell Companion to the Philosophy of Religion. 
a man can be at home in the world-whether he can find it a good world despite the ill. Not that I am supposing that there is a kind of education that could guarantee the outcome, but rather this: by being brought into contact with forms of understanding ... in which some good is to be encountered, some wonder to be seen, whether in nature or the work of human beings, a person might be helped to see the beauty of reality, helped to live more fully, helped to be glad that he is alive. (Roy Holland, Against Empiricism (Oxford: Blackwell 1980), p.59)

The last thing to say about the diachronic conception of the problem of evil is to add that in quite a number of cases of specific evils that they have experienced, Theists in practice are very likely to say that God has provided a resolution. They found themselves in some crisis or other; and they either waited to see what God would do, or bothered God about the crisis, or both; and God did do something about it. That is what Cromwell's followers, John Milton for example, said about the founding of the English "Commonwealth" in 1649; it is what most English people thought about the defeat of the Armada in 1588, and what a substantial proportion of the English thought about Bonaparte's failure to invade in 1798 and Hitler's failure to invade in 1940; it is what many believers on the run from a whole variety of psychotic regimes have said about their experience of (as they saw it) being protected from capture and death; it is what millions of obscure believers have taken to happen in their own experience at all sorts of life-junctures-finding a spouse, for example; most saliently of all to a Christian, it is what Jesus' disciples said about the resurrection.

The point here is not whether such claims made by Theists are contestable or not (of course they are contestable). The point is only that they are entirely characteristic of Theism. In this respect as in so many others, real Theism could not be less like the caricature Theisms that so often dominate philosophical debate-for instance, Antony Flew's undetectable gardener. ${ }^{23}$ Pace Flew, Theists typically take their God to be a highly detectable gardener. Indeed they think they've detected him. Or he them. ${ }^{24}$

${ }^{23}$ Antony Flew, „Theology and Falsification,” University, 1950-51.

${ }^{24}$ Thanks for their comments to Chris Belshaw, Nick Everitt, Jeffrey John, Eleonore Stump, and an audience at the University of Northampton. 